\title{
STUDIES ON TASMANIAN HEPATICAE. I. THE GENUS ADELANTHUS
}

\author{
by J.J. Engel \\ (with four text-figures)
}

Adelanthus is represented in Tasmania by four species: A. bisetulus, A.falcatus, A. gemmiparus and A.occlusus. A key is presented to distinguish these species of liverworts, and comments are provided on taxonomic characters and ecology. Adelanthus gemmiparus is recorded from Tasmania for the first time.

Key Words: Adelanthus, liverworts, Tasmania.

In BAŇKS, M.R. et al. (Eds), 1991 (31:iii): ASPECTS OF TASMANIAN BOTANY - A TRIBUTE TO WINIFRED CURTIS. Roy. Soc. Tasm. Hobart: 7-11. https://doi.org/10.26749/rstpp.124.2.7

\section{INTRODUCTION}

The Adelanthaceae have two genera. Adelanthus, with 12 species, is well represented in southern temperate and neotropical regions. Two species occur in Europe, and one is known only from Bomeo. Wettsteinia has four species and is known from southem South America,
Juan Femández, the Falkland Islands, New Zealand and the Indomalayan region.

Four species of Adelanthus occur in Tasmania, one of which has not previously been recorded from the state; all of them also occur in New Zealand. The four species may be distinguished by the following key.

\section{KEY TO THE TASMANIAN SPECIES OF ADELANTHUS}

1. Leaf insertion in dorsal half succubously decurrent; leaf apex (on vigorous shoots) with 2 teeth or awns, rarely without armature; leaf cells relatively thin walled, trigones medium to large; subapical leaf cells 24-35 mm wide and long. Leaves with dorsal and ventral margins entire. Plants commonly corticolous ...... A. bisetulus

1. Leaf insertion in dorsal half nearly transverse, not or feebly decurrent; leaf apex entire or variously dentate, but not consistently with 2 teeth or awns; leaf cells \pm uniformly thick walled, trigones absent or nearly so; subapical leaf cells 16-26 m wide and long. Plants on soil, rock or bryophyte covered logs ........... 2

2. Median leaves of vigorous shoots longer than wide, symmetric and not ampliate ventrally; leaves laterally spreading to suberect; shoot tips straight, rigid. Leaves without distinct differentiation of a vitta of strongly elongate cells

A. gemmiparus

2. Median leaves of vigorous shoots wider than long, strongly asymmetric, the ventral portion distinctly ampliate; leaves erect or suberect, decurved-homomallous; shoot tips often recurved ....

3. Leaves, at least in distal sectors of shoots, sharply and irregularly toothed (only rarely weakly toothed); distal leaves becoming progressively smaller, often becoming longer than broad; leafy, erect shoots commonly branched, the branching sometimes dendroid A. falcatus

3. Leaves usually completely entire; leaves \pm similar in size and form throughout, the shoot apices not smaller leaved; leafy, erect shoots nearly always unbranched 


\section{Adelanthus bisetulus (Steph.) Grolle (fig. 1)}

\section{Synonyms}

Tylimanthus bisetulus Steph., Spec. Hep. 6(1922) 246; Adelanthus bisetulus (Steph.) Grolle, J. Hattori bot. Lab. 35 (1972) 359. Lectotype (fide Grolle, 1972): New Caledonia, in jugo Dogny, 1040 m, Lerat 361 (non vidi).

Marsupidium piliferum Steph., Bull. Herb. Boissier

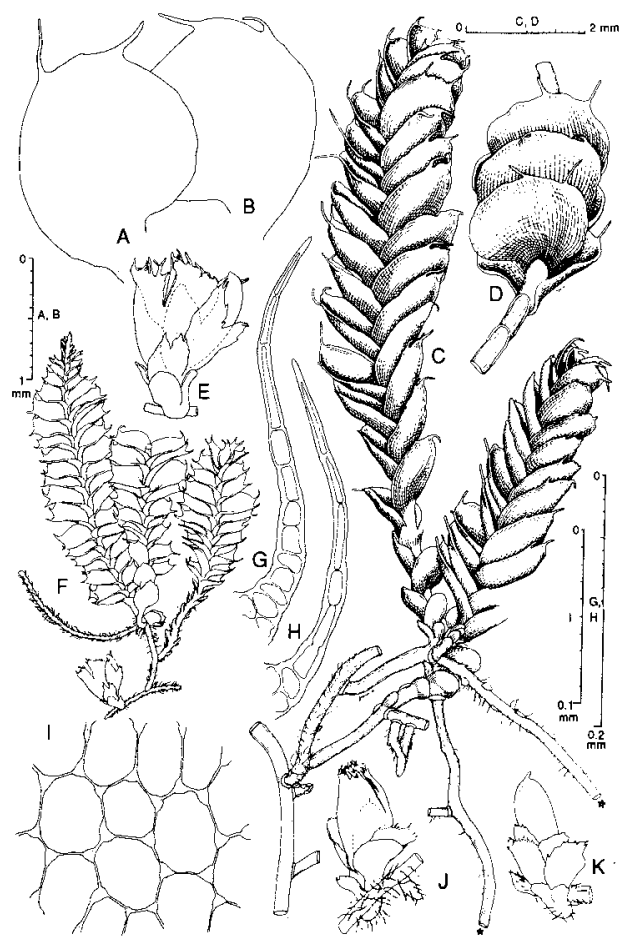

FIG. 1 - Adelanthus bisetulus (Steph.) Grolle: $(A, B)$ leaves, $(C)$ portion of plant showing system of copiously branched, prostrate stolons and erect leafy shoots $(\star=$ shoots severed), (D) sector of leafy shoot (note leaf insertion), lateral view, $(F)$ plant with leaves widely spreading, $(E, J, K)$ gynoecial branches, $(G, H)$ awns of same leaf apex, (I) median leaf cells. $(A-D$ - from Engel 14024,Tasmania, Cradle Mountain-Lake St Clair National Park, Ballroom Forest; $E, F, J, K$ - after Grolle (1972); G, H-from Engel 13798, Tasmania, near Scotts Peak road; I - from Norris 26966. Tasmania, trail to Adamsons Peak.)
8(8) (1908, 602. (= Spec. Hep. 3: 386), syn. fide Grolle (1972); Pseudomarsupidium piliferum (Steph.) Herz. in Grolle, Trans. Br. bryol. Soc. 4 (1963) 443. [Non Adelanthus piliferus Horik., J. Sci. Hiroshima Univ., Ser. B, Div. 2, bot. 2 (1934) 184.] Lectotypes: Australia, New South Wales, Ferd. von Müller (non vidi).

Adelanthus humilis Steph., Spec. Hep. 6 (1924) 446. syn. fide Grolle (1972). Original material: New Caledonia, 1909, Lerat 207 (non vidi).

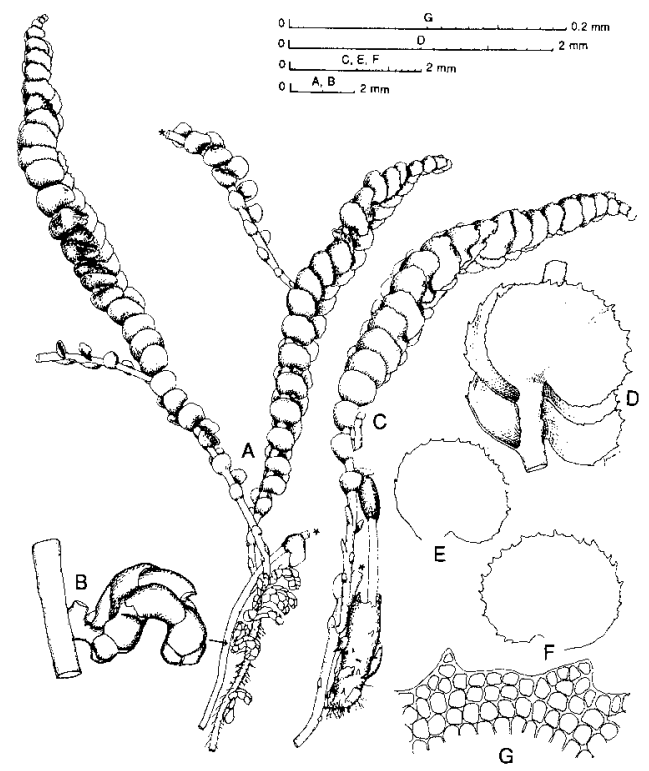

FIG. 2 - Adelanthus falcatus (Hook.) Mitt.: (A) plant with numerous basal androecia ( $\star=$ shoots severed), $(B)$ detail of the androecial branch indicated by arrow on $(A),(C)$ sporophyte-bearing plant $(\star=$ shoot severed), (D) sector of erect leafy branch, lateral view, $(E, F)$ leaves, $(G)$ portion of leaf apex. $(A, B$ - from Engel 14135A, Tasmania, just west of Watersmeet, west of southwest end of Lake St Clair; C - from Norris 27836, Tasmania, between Lake Solitude and Little Hugel, Cradle Mountain-Lake St Clair National Park; D, F - from Engel 13904, Tasmania, Weindorfers Forest; $E, G$ from Engel 15366, Tasmania, Mt Arthur, Pipers River.) 


\section{Comments}

The conspicuous pair of stiff, bristly, often clawlike, usually hyaline teeth or awns at the leaf apex (fig. 1A-D) will identify the species in the field. The awns are composed of elongate, very thick-walled cells (fig. $1 \mathrm{G}, \mathrm{H}$ ).

Shoots with erect leaves appear quite different from those on which the leaves are spreading (e.g. fig. 1C,F).

\section{Ecology}

Adelanthus bisetulus is usually corticolous in a variety of forest types between 500 and $1050 \mathrm{~m}$ a.s.l. (e.g. Nothofagus-Eucalyptus, Nothofagus-EucalyptusAtherosperma, Nothofagus-Athrotaxis). It is rarely noncorticolous, and then occurs over a thin layer of soil on a cliff face in a mosaic of Gymnoschoenus, subalpine shrubs, Nothofagus cunninghamii and rocky outcrops $(1000 \mathrm{~m})$.

\section{Adelanthus falcatus (Hook.) Mitt.}

$$
\text { (fig. 2) }
$$

\section{Synonyms}

Jungermannia falcata Hook., Musci Exot. 1 (1818) tab. 89 [non $J$. falcata Raddi, Jungermanniogr. Etrusca 22 (1818) (= Diplophyllum albicans (L.) Dum.)]. Plagiochila falcata (Hook.) G.L.\& N., Syn. Hep. (1847) 649. [non P. falcata Steph., Bull. Herb. Boissier 2(10) (1902) 879 (= Spec. Hep. 2: 248)]. Adelanthus falcatus (Hook.) Mitt., J. Proc. Linn. Soc., bot. 7 (1864) 243. Odontoschisma falcata (Hook.) Trev., Memorie Ist. lomb. Sci. lett. III(4) (1877) 419. Calyptrocolea falcata (Hook.) Schust., Revue bryol. lichén. 34 (1966[1967]) 689. Original material: New Zealand, South Island, Dusky Bay, 1791, Menzies (non vidi).

Plagiochila pusilla Mont., Annls Sci. nat. bot. II(19) (1843) 246, syn. fide Inoue \& Schuster (1971). Jungermannia pusilla (Mont.) Hook. f. \& Tayl., London J. Bot. 3 (1844) 578. non J. pusilla L., Spec. Pl. ed. 1. (1753) 1136. Original material: "NovaHollandia (Van Diemen)," sin. coll. (non vidi).

Plagiochila intermixta Col., Trans. Proc. N.Z. Inst. 21 (1888[1889]) 49, syn.fide Stephani (1892). Original material: New Zealand, Dannevirke, 1888, Colenso (non vidi).

Plagiochila subpetiolata Col., Trans. Proc. N.Z. Inst. 21(1888[1889]) 49, syn. fide Stephani (1892). Original material: New Zealand, Whakatane Co., near L. Waikare, 1887, Hamilton (non vidi).

Marsupidium capillare Berggr., New Zealand Hep. (1898) 36 f. 25, syn. fide Hodgson (1970). Plagiochila capillaris (Berggr.) Hodgs., Trans. R.
Soc. N.Z. 85 (1958) 581 [non P. capillare Schiffn. in Stephani, Spec. Hep. 6 (1918) 137]. Adelanthus capillaris (Berggr.) Hodgs., Trans. R. Soc. N.Z., bot. 3 (1965) 77. Holotype: New Zealand, South Island, Canterbury Prov., Castle Hill, Berggren 3156 (non vidi).

Plagiochila appressifolia Steph., Spec. Hep. 6 (1917) 124, syn.fide Grolle (1972). Holotype: Ne w Zealand, Mamaku, $600 \mathrm{~m}$, Fleischer (non vidi).

Plagiochila inaequalis Steph., Spec. Hep. 6 (1918) 169. syn. fide Inoue \& Schuster (1971). Holotype: New Zealand, Mt Winterslow, Beckett (non vidi).

\section{Comments}

In keying plants of this species, the leaf armature on more distal leaves should be carefully examined. The leaves toward the shoot base are frequently entire, with armature becoming progressively more abundant and larger distally. The leaves are armed at the apex and ventral margin, but the armature stature is quite variable. Typically the leaves are coarsely and sharply serrate (fig. 2D-F) but, in some plants, leaf dentition is quite small. Further, some plants, while having a few branches with leaf armature typical of this species, possess some leafy branches with completely entire leaves.

There is a rather common phase of the species in which plants are smaller and leaves more sparingly armed. In this form there is a distinct proportion of lower leaves which are completely entire. As mentioned above, the distal portions of leafy shoots should be carefully checked, since the upper leaves usually bear serration typical of the species.

Schuster (1966: 689), in his key to the New Zealand species of "Calyptrocolea", states for " $C$." falcata, "upper leaves progressively smaller, becoming as long or longer than broad." While this is a useful feature, included in the present key, the character is not always expressed. Exceptions sometimes may be found on shoots which are erect throughout, i.e. not cernuous to subcircinnate; on these plants the leaves remain wider than long and do not markedly decrease in size toward the shoot apex.

Larger plants with decidedly sparse leaf armature should be treated with special care to avoid possible confusion with $A$. occlusus. Examples of this facies are Engel 13829 (Gordon River just east of confluence with Serpentine River, westnorthwest of Strathgordon, $350 \mathrm{~m}$ a.s.l.) and Engel 13991 (Cradle Mountain-Lake St Clair National Park, Ballroom Forest, southwest side of Lake Dove, $950-1050 \mathrm{~m}$ a.s.1.). 


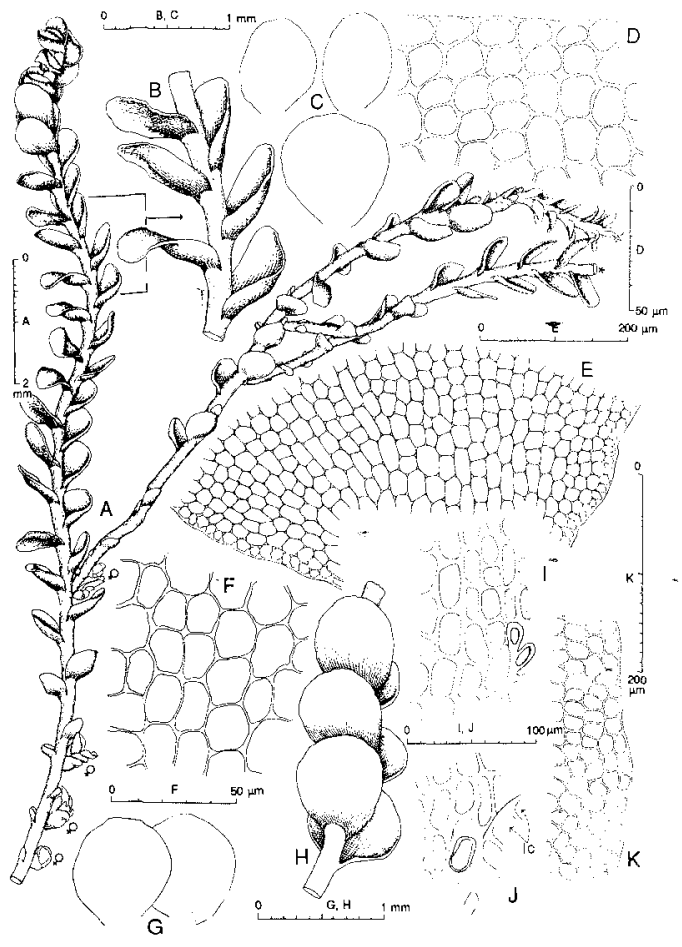

FIG. 3 - Adelanthus gemmiparus (Schust.) Hodgs.: (A) erect leafy shoot with basal gynoecia, dorsal view, $(B)$ sector (indicated by bracket) of shoot shown in $(A)$, dorsal view, $(C)$ three leaves to one scale, $(D)$ portion of leaf apex, $(E)$ leaf base, $(F)$ median leaf cells, $(G)$ leaves, $(H)$ sector of leafy shoot, lateral view, $(I, J)$ stem cells and underleaves, (I) the underleaf consisting of a pair of laterally juxtaposed cells and associated slime papillae, $(J)$ one cell and slime papillae $\left(l_{c}=\right.$ leaf cell $),(K)$ median sector of leaf margin. (All from Norris 28517, Tasmania.)

\section{Ecology}

Adelanthus falcatus is rather common in medium to upper-level forests, between 300 and $1100 \mathrm{~m}$ a.s.l., where it commonly occurs on rocks and both boulder faces and crevices, particularly where a thin layer of soil has accumulated. The species is rare below $300 \mathrm{~m}$. In wetter sites it occurs on rocks and boulders of stream banks and beds as well as cliff faces near waterfalls. Adelanthus falcatus less frequently occurs on logs, and then usually only when they are nearly or totally covered
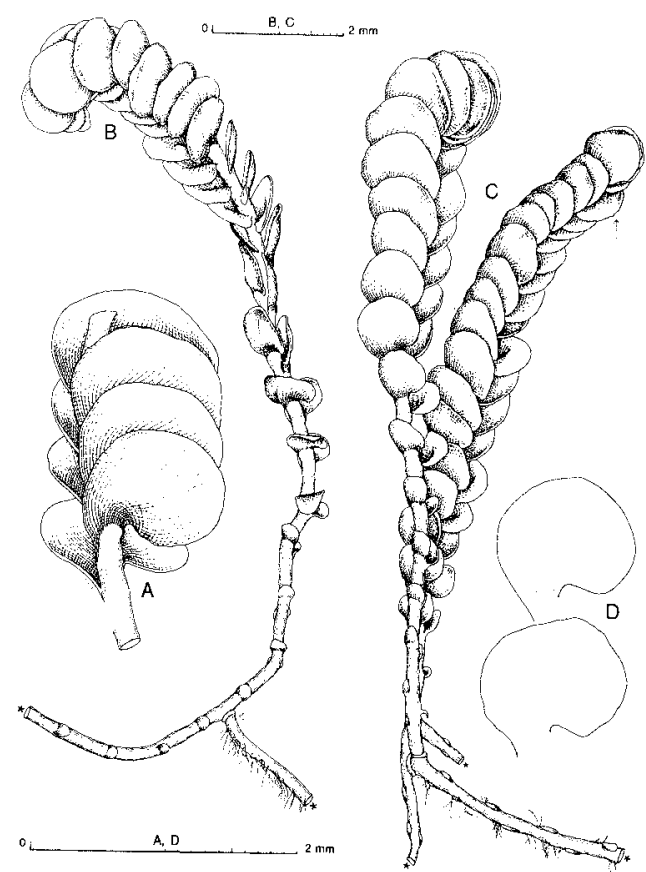

FIG. 4 -- Adelanthus occlusus (Hook. f. \& Tayl.) Carringt.: (A) sector of leafy shoot, lateral view, $(B, C)$ erect leafy shoots and, at base, stolons, lateraldorsal views ( = shoots severed; note sparsely denticulate leaf at arrow), (D) leaves. (All from Engel 16257, Tasmania, southeast of-Black Bluff.)

by bryophytes. In subalpine situations the species occurs over soil of moist, shaded boulder crevices (1050$1175 \mathrm{~m}$ a.s.1.).

\section{Adelanthus gemmiparus (Schust.) Hodgs.} (fig. 3)

\section{Synonyms}

Calyptrocolea gemmipara Schust., Revue bryol. lichén. 34 (1966[1967]) 695. Adelanthus gemmiparus (Schust.) Hodgs., Trans. R. Soc. N.Z., biol. Sci. 11 (1970) 241. Holotype: New Zealand, South Island, Westland, approximately $1 \mathrm{~km}$ below Haast Pass, Schuster 53384 (hb. Schuster!).

\section{Comments}

Well-developed plants of this species have been confused with Hepatostolonophora rotata (Hook. f. \& Tayl.) Engel, due to resemblance in appearance and colour.

Well-developed shoots have many leaves inserted and oriented exactly as described in Schuster (1966: 696), i.e. "succubously inserted except dorsally, where 
virtually transversely inserted (as a consequence, the dorsal base of leaf elevated sharply and strongly above stem, standing stiffly erect)". Mature leaves are almost transversely oriented (fig. 3B,H). The leaf insertion and orientation, coupled with general similarity in leaf shape, in particular lend the Hepatostolonophora aspect to the plants.

As previously mentioned (Engel 1979: 102),

"The presence of inconspicuous but distinct underleaves will immediately distinguish $H$. rotata. I have also utilized gynoecial position to confirm the disposition of specimens, i.e. gynoecia are restricted to short, abbreviated ventralintercalary branches in A. gemmiparus."

Since several genera contain $A$. gemmiparus "lookalikes", a careful search for gynoecia or androecia should be made for generic confirmation.

Hodgson (1970), when making the combination in Adelanthus, cites the complete pagination for the Schuster paper in which the basionym appeared, rather than the specific page.

\section{Ecology}

The species, which has not previously been recorded in Tasmania, is rare, occurring on a moist, diffusely lit rock outcrop in a low Eucalyptus coccifera forest on a scree slope at $900 \mathrm{~m}$ a.s.1.

\section{Specimens Examined}

Tasmania: north side of Lake Fenton, Mt Field National Park, Norris 28517 (F).

\section{Adelanthus occlusus (Hook. f. \& Tayl.) Carring. (fig. 4)}

\section{Synonyms}

Jungermannia occlusa Hook. f. \& Tayl., London J. Bot. 3 (1844) 369. Alicularia occlusa (Hook. f. \& Tayl.) G.L. \& N., Syn. Hep. (1846) 619. Adelanthus occlusus (Hook. f. \& Tayl.) Carring., Trans. bot. Soc. Edinb. 10 (1870) 381. Odontoschisma occlusum (Hook. f. \& Tayl.) Trev., Memorie Ist. lomb. Sci. lett. III(4) (1877) 419. Jamesoniella occlusa (Hook. f. \& Tayl.) Steph., Bull. Herb. Boissier 1(1) (1901) 1039 (=Spec.Hep. 2: 102). Calyptrocolea occlusa (Hook. f. \& Tayl.) Schust., Revue bryol. lichén. 34 (1966[1967]) 692. Original material: Campbell Is., Hooker (non vidi).

Plagiochila orbiculata Col., Trans. Proc. N.Z. Inst. 21 (1888[1889]) 48, syn.fide Hodgson (1970). Original material: New Zealand, East TaupoCo., Mt Tongariro, 1887, Hill (non vidi).

\section{Comments}

The leaves of this species normally are completely entire. Occasionally, sporadic leaves toward the shoot apex have a few isolated small teeth (fig. 4C, arrow).

\section{Ecology}

Rare in Tasmania, occurring at $1000 \mathrm{~m}$ a.s.l. in a mosaic of Gymnoschoenus, subalpine shrubs, Nothofagus cunninghamii and rocky outcrops.

\section{Specimens Examined}

Tasmania: ridge southeast of Black Bluff near junction of access road to plateau area and road to Devonport gold mines, south of Burnie, Engel 16257 (F) .

\section{ADELANTHUS SPECIES EXCLUDED FROM TASMANIA}

Plagiochila magellanica Lindenb. Ð Adelanthus magellanicus (Lindenb.) Mitt. (= Adelanthus lindenbergianus (Lehm.) Mitt.). According to Grolle (1972) the Australasian records of A. magellanicus are actually $A$. occlusus.

\section{ACKNOWLEDGEMENTS}

The author extends thanks to Zorica Dabich for preparing the habitus figures.

\section{REFERENCES}

Engel., J.J., 1979: Austral Hepaticae X. A revision of Hepatostolonophora Engel et Schust., nom. nov. (Hepaticae).J. Hattori bot. Lab. 46: 91-108, figs 18.

Grolle, R., 1972: Zur Kenntnis von Adelanthus Mitt. $J$. Hattori bot. Lab. 35: 325-370, pls 1-11.

Hodgson, E.A., 1970: New Zealand Hepaticae (Liverworts) XIX. Adelanthus Mitten, A New Zealand genus. Trans. R. Soc. N.Z., biol. sci. 11: 239-242.

Inoue, H. \& Schuster, R.M., 1971: A monograph of the New Zealand and Tasmanian Plagiochilaceae. I. Hattori bot. Lab. 34: 1-225, figs 1-77.

SchusTer, R.M., 1966: Studies on Hepaticae, VII-X. On Adelanthus Mitten and Calyptrocolea Schuster, gen. n. Rev. Bryol. Lichénol. 34: 676-703.

Stephani, F., 1892: A revision of Colenso's Hepaticae, with descriptions of new species collected by him. J. Linn. Soc., Bot. 29: 263-280, pls 26-28.

(accepted 4 May 1990)

\section{J.J. Engel}

Department of Botany, Field Museum of Natural History, Roosevelt Road at Lake Shore Drive, Chicago, Illinois 60605, USA 